\title{
Nutritional and antioxidant potential of a desert underutilized legume - tepary bean (Phaseolus acutifolius). Optimization of germination bioprocess
}

\author{
Fernando SALAS-LÓPEZ ${ }^{1}$, Roberto GUTIÉRREZ-DORADO ${ }^{1,2}$, Jorge MILÁN-CARRILLO ${ }^{1,2}$, \\ Edith Oliva CUEVAS-RODRÍGUEZ ${ }^{1,2}$, Vicente Adrián CANIZALEZ-ROMAN ${ }^{2,3}$, \\ Claudia del Rosario LEÓN-SICAIROS ${ }^{2}$, Cuauhtémoc REYES-MORENO ${ }^{1,2 *}$
}

\begin{abstract}
Tepary bean (Phaseolus acutifolius) is a short life cycle legume, resistant to many diseases and drought, originally from the deserts and semi-arid environment of Northwestern Mexico and the Southwestern US. Its mature seeds are scarce consumed, and their high protein and carbohydrate contents are underutilized. The aim was to identify optimal germination conditions for producing a functional flour with máximum values of protein content (PC), antioxidant activity (AoxA), and total phenolic content (TPC). A central composite rotatable experimental design with two factors [Germination temperature $\left(\mathrm{GT}, 20-40{ }^{\circ} \mathrm{C}\right) / \mathrm{Germination}$ time (Gt, 10-170 h)] in five levels was used (13 treatments). Optimized conditions of germination to obtain a functional tepary bean flour were $\mathrm{GT}=32{ }^{\circ} \mathrm{C} / \mathrm{Gt}=120 \mathrm{~h}$. Germination was an effective strategy to increase PC $(+57.5 \%)$, AoxA $(+188-318 \%)$, TPC (+232\%), flavonoid content $(+114)$, and dietary fiber $(+246 \%)$ in tepary bean seeds. Therefore, the optimized germinated tepary bean flour could be used as a source of natural antioxidants, protein, and dietary fiber in the formulation of functional foods.
\end{abstract}

Keywords: tepary bean; antioxidant activity; germination; optimization.

Practical Application: Functional food from an underutilized legume was obtained by optimization of the germination bioprocess.

\section{Introduction}

The year of 2016 was declared "The International Year of Pulses" by the 68th United Nations General Assembly. The term "pulses", as described in the Food and Agriculture Organization definition, is exclusively for crops harvested solely for the dry seed of leguminous plants. In developing countries, legumes have an important role in human nutrition; in these countries, people include legume in its dietary pattern to complement lack of some essential amino acids from cereals, mainly low-income groups (Kalogeropoulos et al., 2010). The grains of legumes contain a good level of proteins, vitamins, minerals, dietary fiber, and slow release carbohydrates (Frassinetti et al., 2015). Also, they are important source of natural antioxidants, as such phenolic compounds. These dietary antioxidants have the property of act as free radical scavengers, reducing agents, chelating agents of prooxidant metals and quenchers of the formation of singlet oxygen, which allows them to protect the cell against oxidative damage (Doblado et al., 2007). In literature, it has been widely reported that these compounds have the property of reducing different diseases such as cancer, heart disease, hypertension, and diabetes. They also have the ability to inhibit platelet aggregation in plasma; as well as cyclooxygenase, antibacterial, antiviral, anti-inflammatory, anti-allergenic, and histamine release activities. Many of these health benefits, present in these bioactive compounds, are mainly due to their antioxidant
properties.(López-Amorós et al., 2006; Fernandez-Orozco et al., 2009; Cevallos-Casals \& Cisneros-Zevallos, 2010).

Some nontraditional underutilised legumes such as beach bean (Canavalia maritima), marama bean (Tylosema esculentum), rice bean (Vigna umbellata), winged bean (Psophocarpus tetragonolobus), bambara nut (Vigna subterranea), and tepary bean (Phaseolus acutifolius) have recently gained attention as highly nutritive pulses with outstanding productivity. Most of the nutritional requirements of the rural population are still met by legumes, which constitute an essential source of proteins (Katoch, 2013; Sridhar \& Niveditha, 2014). The tepary bean (Phaseolus acutifolius) is a short life cycle and drought resistant legume initially from the deserts and semi-arid environment of Northwestern Mexico and Southwestern US. It is recognized for its low requirements of moisture with high adaptation to warm climates, i.e., is heat tolerant, and for its resistance to many diseases (Salgado et al., 1994; Miklas \& Staveley, 1998; López et al., 2005). The main nutritional significance of tepary bean consumption is its contribution of nutriments; its mature seeds contain $13.0-32.2 \%$ proteins, $0.4-2.4 \%$ lipids, and $65.3-69.1 \%$ carbohydrates (Scheerens et al., 1983). However, the high content of proteins and carbohydrates in this legume is underutilized, due to tepary bean seeds are poorly consumed. 
Germination is considered both economical and straightforward bioprocess to improve the nutritive value of grains by causing appropriate changes in the nutrient availability, texture, sensorial characteristics, and antioxidant and nutraceutical properties (Fernandez-Orozco et al., 2009; Perales-Sánchez et al., 2014). In the germination bioprocess the compounds present in the seeds change drastically; there is degradation of storage compounds and synthesis of structural and cellular components. During germination there are also important changes in the antioxidant compounds of the seeds, such as vitamins and secondary metabolites (Kuo et al., 2004). The germination bioprocess enhances the nutritional quality of seeds by expanding the levels of available carbohydrates, free amino acids, dietary fiber, and other components. Also improving the functionality of the grains due to the subsequent increments in antioxidant capacity and related bioactive compounds (Khattak et al., 2008; Cevallos-Casals \& Cisneros-Zevallos, 2010; Feng et al., 2010; Shi et al., 2010; Wu et al., 2011). Polyphenols is one of the manly groups of antioxidant compounds that increase during germination; they have the capacity to reduce the oxidative damage of the cell membranes ocasioned by reactive free radicals, prevent the oxidative damage in foods as well as in the human body (López-Amorós et al., 2006; Fernandez-Orozco et al., 2009). In addition, the consumption of dietary phenolic compounds has been related to the reduction of different chronic conditions such as inflammation, cancer, cardiovascular diseases, and some other diseases (Shams-Ardekani et al., 2011).

There isn't any research about the optimization of the germination conditions to increase the antioxidant activity, total phenolic content and nutritional value of tepary bean. Therefore, this study was conducted to find the best germination conditions of tepary bean seeds that would maximize the antioxidant activity, total phenolic and protein contents, and obtain functional flours with enhanced nutritional properties, and antioxidant potential.

\section{Materials and methods}

\subsection{Materials}

The tepary bean seeds were acquired in a local Rafael Buelna Market, Culiacan, Sinaloa, México. The tepary bean seeds were cleaned and stored in tightly sealed containers at $4{ }^{\circ} \mathrm{C}$ until use.

\subsection{Methods}

\section{Production of Germinated Tepary Bean Flours (GTBF)}

A portion of $400 \mathrm{~g}$ of tepary bean seeds was soaked in $1,000 \mathrm{~mL}$ of $0.1 \%$ sodium hypochlorite for $10 \mathrm{~min}$. Then, these seeds were washed with distilled water and soaked $\left(25^{\circ} \mathrm{C} / 12 \mathrm{~h}\right)$ with $1,000 \mathrm{~mL}$ of distilled water. The hydrated seeds were placed in germination trays with small holes at the bottom. The dishes were introduced in the germination chamber with controlled temperature. The relative humidity within the house was maintained in the range $80-90 \%$ using recipes with distilled water. The germination conditions employed were germination temperature $(\mathrm{GT})$ : range $=20-40{ }^{\circ} \mathrm{C}$, and germination time $(\mathrm{Gt})$ : range $=10-170 \mathrm{~h}$ (Table 1$)$. The germination of seeds was carried out under $50 \%$ light $/ 50 \%$ darkness periods of the germination time daily; light white was used as ilumitanion
Table 1. Experimental design ${ }^{a}$ used to obtain different combinations of germination temperature/germination time for producing germinated tepary bean flours, and experimental results for the studied response variables.

\begin{tabular}{|c|c|c|c|c|c|}
\hline \multicolumn{3}{|c|}{ Process variables } & \multicolumn{3}{|c|}{ Response variables } \\
\hline Assay $^{b}$ & $\begin{array}{c}\text { Germination } \\
\text { temperature } \\
\left({ }^{\circ} \mathrm{C}\right)\end{array}$ & $\begin{array}{l}\text { Germination } \\
\text { time (h) }\end{array}$ & $\begin{array}{l}\text { Protein } \\
\text { content }^{c}\end{array}$ & $\begin{array}{l}\text { Antioxidant } \\
\text { activity }^{\mathrm{d}}\end{array}$ & $\begin{array}{c}\text { Total } \\
\text { phenolic } \\
\text { content }^{\mathrm{e}}\end{array}$ \\
\hline 1 & 23 & 33 & 228 & 11885 & 322 \\
\hline 2 & 37 & 33 & 218 & 13176 & 369 \\
\hline 3 & 23 & 146 & 237 & 15108 & 428 \\
\hline 4 & 37 & 146 & 321 & 24555 & 302 \\
\hline 5 & 20 & 90 & 250 & 11744 & 438 \\
\hline 6 & 40 & 90 & 263 & 21273 & 363 \\
\hline 7 & 30 & 10 & 222 & 11397 & 262 \\
\hline 8 & 30 & 170 & 305 & 28098 & 272 \\
\hline 9 & 30 & 90 & 247 & 25482 & 398 \\
\hline 10 & 30 & 90 & 269 & 27212 & 388 \\
\hline 11 & 30 & 90 & 253 & 25695 & 352 \\
\hline 12 & 30 & 90 & 275 & 28055 & 363 \\
\hline 13 & 30 & 90 & 261 & 24086 & 375 \\
\hline
\end{tabular}

${ }^{\mathrm{a} C e n t r a l ~ c o m p o s i t e ~ r o t a t a b l e ~ d e s i g n ~ w i t h ~ t w o ~ f a c t o r s ~ a n d ~ f i v e ~ l e v e l s, ~} 13$ assays; ${ }^{\mathrm{b}} \mathrm{Does}$ not correspond to order of processing, ${ }^{\mathrm{c}} \mathrm{g} / \mathrm{kg}, \mathrm{DW},{ }^{\mathrm{d}} \mu \mathrm{mol}$ Trolox equivalents (TE)/100 g (DW), ${ }^{\mathrm{e}} \mathrm{mg}$ Gallic acid equivalents (GAE)/100 g sample (DW).

source [fluorescent tubes (16 W/2,700 K), Tecno Lite, China)]. The samples in the germination trays were wetted by spraying water containing $0.02 \%$ sodium hypochlorite twice daily for the days of germination selected for each treatment. The resulting processed tepary bean seeds were dried $\left(50{ }^{\circ} \mathrm{C} / 8 \mathrm{~h}\right)$, tempered $\left(25^{\circ} \mathrm{C}\right)$, and ground $(80$-US mesh $=0.180 \mathrm{~mm})$ to obtain germinated tepary bean flours (GTBF). GTBF were packed and kept at $4{ }^{\circ} \mathrm{C}$ in tightly sealed containers until further analysis.

\section{Extraction of free and bound phenolic compounds}

Free phenolic compounds were extracted according to Dewanto et al. (2002), with some modification. Half gram (0.5 g) of a dry ground sample was shaking in $10 \mathrm{~mL}$ of chilled ethanol-water (80:20, v/v) using a tube rotator $(50 \mathrm{rpm} / 10 \mathrm{~min})$. Then, the supernatant was recovered by centrifugation (3000xg, $10 \mathrm{~min}$ ) (Sorvall RC5C, Sorvall Instruments, Dupont, Wilmington, DE, USA), and the extraction step was repeated two more times. The extracts were evaporated to dryness (evaporator type Savant SC250 DDA Speed Vac Plus centrifugal, Holbrook, NY) and stored at low temperature $\left(-20^{\circ} \mathrm{C}\right)$. The methodology reported by Adom \& Liu (2002) was used to extract bound phenolic compounds. The pellets obtained after the extraction of free phenolics compounds were hydrolyzed with $10 \mathrm{~mL}$ of sodium hydroxide $(2 \mathrm{M})$ at $95^{\circ} \mathrm{C}$ and $25^{\circ} \mathrm{C}$ for 30 and $60 \mathrm{~min}$, respectively, using a water bath with agitation $(60 \mathrm{rpm})$. After, chloride acid was employed to neutralization, followed by a remotion of lipids with hexane. The bound phenolic compounds were extracted with $10 \mathrm{~mL}$ of ethyl acetate, repeating the extraction step four times more. The extracts were evaporated to dryness and stored at low temperature $\left(-20^{\circ} \mathrm{C}\right)$. All extractions were made in triplicate. Dry extracts of free and bound phenolic compounds were 
reconstituted in $2 \mathrm{~mL}$ of methanol to measurement of antioxidant activity, and total phenolic and flavonoid compounds contents.

\section{Antioxidant Activity (AoxA)}

Free and bound hydrophilic AoxA were determined using the ABTS radical cation decolourisation assay, and the oxygen radical absorbance capacity (ORAC) assay using a Microplate Reader (Synergy ${ }^{\mathrm{TM}}$ HT Multi-Detection, BioTek, Inc., Winooski, VT, USA). For ABTS assay the extracts were evaluated against a standard of Trolox as a probe as it was described by Re et al. (1999). For ORAC assay the extracts were evaluated against a standard of Trolox with Fluorescein as a probe as described by Ou et al. (2001). The results of both assays were expressed as $\mu \mathrm{mol}$ of Trolox equivalents (TE)/100 g of dry weight (DW) sample. All measurements were made in triplicate.

\section{Total Phenolic and Flavonoid Contents (TPC, TFC)}

Colourimetric methods reported by Singleton et al. (1999) and Heimler et al. (2005) were used to determination of TPC and TFC in free and bound extracts, respectively. A Microplate Reader (Synergy ${ }^{\mathrm{TM}}$ HT Multi-Detection, BioTekInc, Winooski, VT, USA) was used to mesure the absorbance. TPC and TFC were expressed as milligrams of Gallic acid equivalents (mg GAE)/100 g dry weight sample, and milligrams of Quercetin equivalents (mg QE)/100 g dry weight sample. All measurements were made in triplicate.

\section{Proximate composition}

Chemical composition was determinated using official methods (Association of Official Analytical Chemists, 1999). The following methods were used: 925.09B, 920.39C, 960.52 to evaluate moisture, lipids, and protein, respectively.

\section{Soluble and Insoluble Dietary Fiber (SDF/IDF)}

The official method 985.29 of Association of Official Analytical Chemists (1999) was used to evaluate SDF and IDF, employing the assay kit TDF 100-A from Sigma-Aldrich.

\section{In Vitro Protein Digestibility (IVPD)}

The multienzyme assay of Hsu et al. (1977) was used to determinate IVPD. Fifty milliliters of a multienzyme solution were prepared [80 $\mathrm{mg}$ of pancreatic trypsin $(15,600 \mathrm{U} / \mathrm{mg})$, $155 \mathrm{mg}$ of bovine pancreatic chymotrypsin (83.9 U/mg), $65 \mathrm{mg}$ of porcine intestinal peptidase $(102 \mathrm{U} / \mathrm{g})$ and distilled water]. Also, a protein-water suspension was prepared $(6.25 \mathrm{~g}$ of protein/L). The $\mathrm{pH}$ of multienzyme solution and protein suspension was adjusted to 8.0 using $0.1 \mathrm{~N} \mathrm{HCl}$ and $0.1 \mathrm{~N} \mathrm{NaOH}$ solutions. Five milliliters of multienzyme solution were mixed with $50 \mathrm{~mL}$ of the protein suspension employing constant stirring in a water bath at $37^{\circ} \mathrm{C}$. The $\mathrm{pH}$ was measured after $10 \mathrm{~min}$ of transcurred time using a potentiometer. The following equation 1 was used to evaluate IVPD:

IVPD $=210.46-18.10 \mathrm{X}$ where $\mathrm{X}=\mathrm{pH}$ after $10 \mathrm{~min}$. The $\mathrm{pH}$ assay was made by triplicate.

\section{Essential Amino Acid (EAA) analysis}

The method reported by López-Cervantes et al. (2006) was employed to determinate the EAA content. Ten milliliters of $6 \mathrm{M} \mathrm{HCl}$ was mixed with $50 \mathrm{mg}$ of sample, and the mixture was incubated at $110^{\circ} \mathrm{C}$ by $24 \mathrm{~h}$. After, the solution was filtered using vacuum and filter paper. Ultra-pure water was used to dilute the filtrate (final concentration $=0.1 \mathrm{mg} / \mathrm{mL}$ ). Aliquots $(300 \mu \mathrm{L})$ of this solution were dried overnight in a vacuum oven at $60{ }^{\circ} \mathrm{C}$, to be derivatized later with $300 \mu \mathrm{L}$ of FMOC (9-fluorenymethyl-chloroformate). An aliquot $(20 \mu \mathrm{L})$ was analyzed using an analytical column (4.6x250 mm) SGE Hypersil ODS C18 (SGE, Dandenong, Australia) and an HPLC LC5100 with fluorescence detector (GBC, Dandenong, Australia). The mobile phases used were: (1) $30 \mathrm{mM}$ ammonium phosphate ( $\mathrm{pH}$ 6.5) in 85:15 (v/v) water:methanol; (2) 15:85 (v/v) methanol:water; and (3) $90: 10(\mathrm{v} / \mathrm{v})$ acetonitrile:water. To generate the fluorescence, excitation at $270 \mathrm{~nm}$ was employed, and the detection of fluorescence was at $270 \mathrm{~nm}$ of emission. A mix of standard EAA was used to construction of a calibration curve.

To determinate the EAA tryptophan, $25 \mathrm{mg}$ of sample were hydrolysed with three milliliters of $4.2 \mathrm{M} \mathrm{NaOH}$ at $120^{\circ} \mathrm{C}$ by $4 \mathrm{~h}$ in sealed tubes $\left(\mathrm{N}_{2}\right.$ atmosphere). The hydrolysed samples were adjusted to $\mathrm{pH} 9$, filtered and diluted with borate buffer $(\mathrm{pH} 9)$ up to a volume of $50 \mathrm{~mL}$. The solution was centrifugated, and the supernatant was filtered $(0.45 \mu \mathrm{m})$. The methodology described above was employed to analize an aliquot of $20 \mu \mathrm{L}$ of filtrate employing an ultraviolet detector $(280 \mathrm{~nm})$.

\section{Chemical Score (CS)}

The CS of the sample was calculated by identification of the most limiting EAA, when the content of each EAA was compared with that recommended to children and adults ( 3 years and older) by Food and Agriculture Organization (2013). The following equation 2 was used to calculate the CS:

$C S=($ Most limiting EAA content $/$ Recommended EAA requirement $) \times 100$

\section{Calculated Protein Efficiency Ratio (C-PER)}

The C-PER was evaluated according official method (Association of Official Analytical Chemists, 1999), using the IVPD and the EAA composition of the sample.

\section{Optimization by Response Surface Methodology (RSM)}

A central composite rotable experimental design (CCRED) was used, employing two factors [Germination temperature (GT), germination time $(\mathrm{Gt})$ ] and three response variables [protein content (PC), antioxidant activity (AoxA), and total phenolic content (TPC)] (Table 1). The stepwise regression procedure was applied to obtain reproducible prediction models (second-order polynomial) to each response variable. To the optimization of the germination conditions of tepary bean, the graphical method (conventional method) of the RSM was used to maximize PC, AoxA, and TPC. For this, contour graphs for each response 
variable were constructed using the prediction experimental models obtained, which were superimposed to obtain a contour plot containing the optimal conditions (optimal GT and Gt) for producing optimized germinated tepary bean flour (OGTBF). The RSM analyses was realized using the software Design-Expert version 7.0.0 (Stat-Ease, Minneapolis, MN, USA). One-way analysis of variance (ANOVA) and Duncan's multiple range test to means comparisons were applied to the results of the evaluated properties in OGTBF and unprocessed tepary bean flour (UTBF) using a 5\% significance level.

\section{Results and discussion}

\subsection{Predictive Models for Protein Content (PC), Antioxidant Activity $\left(A_{o x} A\right)$ and Total Phenolic Content (TPC) of Germinated Tepary Bean Flours (GTBF)}

The PC, AoxA, and TPC experimental values of the GTBF varied from 218 to $321 \mathrm{~g} / \mathrm{kg}$ (DW), 11,397 to $28,098 \mu \mathrm{mol}$ TE/100g sample (DW), and 262 to $438 \mathrm{mg} \mathrm{GAE} / 100 \mathrm{~g}$ sample (DW), respectively (Table 1). Second order polynomial models showing the relationships among PC, AoxA, and TPC and process variables were obtained by regression. These prediction models included the linear, quadratic and interaction terms of GT and Gt that were significant $(\mathrm{p} \leq 0.05)$ for each of the response variables studied, except the AoxA response, which contains the interaction term between GT and Gt that was not statistically significant $(\mathrm{p}=0.08)$. This interaction term was included in the AoxA prediction model to achieve a better level of satisfaction (suitability and fit) in the modelling of this response variable. Predictive models using uncoded variables for the response variables (PC, AoxA, and TPC) (Equations 3, 4 and 5) were:

$$
\begin{aligned}
& \mathbf{P C}=257.7+11.5(\mathrm{GT})+28.6(\mathrm{Gt})+23.5(\mathrm{GT})(\mathrm{Gt}) \\
& \mathrm{AoxA}=\mathbf{2 6 1 0 5 . 8 9}+\mathbf{3 0 2 6 . 7 1}(\mathrm{GT})+4777.54(\mathrm{Gt})- \\
& \mathbf{5 2 8 5 . 4 6}(\mathrm{GT})^{2}-\mathbf{3 6 6 5 . 8 9}(\mathrm{Gt})^{2}+2038.83(\mathrm{GT})(\mathrm{Gt}) \\
& \text { TPC }=375.32-23.07(\mathrm{GT})+18.20(\mathrm{GT})^{2}-48.70(\mathrm{Gt})^{2}-43.11(\mathrm{GT})(\mathrm{Gt})
\end{aligned}
$$

A good estimated regression model shall explain the variation of the dependent variable in the sample. There are tests of hypotheses about the model parameters that help to measure the effectiveness of the model. The first of all these tests required for the error term $\left(\varepsilon_{i}\right)$ to be normally and independently distributed with mean zero and variance $s^{2}$. Likewise, a good predictive model should have an adjusted determination coefficient $\left(\mathrm{R}^{2}\right)$ $\geq 0.80$, coefficients of variance $(\mathrm{CV})$ values $\leq 10 \%$, a significant level of $\mathrm{p} \leq 0.05$, and lack of fit test $>0.1$. The normal probability of residuals was graphed (graphs no-showed) for each response variable to check normality assumption of data. The residuals plots obtained approximately along a straight line, which means that the normality assumption was satisfied by the analyzed responses. The difference between the observed and the corresponding fitted value $\left(\mathrm{y}_{\mathrm{i}}, \hat{\mathrm{Y}}_{\mathrm{i}}\right)$ by the experimental model is the error term, that is, $e_{i}=y_{i}-\hat{Y}_{i}$. As a result of this assumption, observations $y_{i}$ were also normally and independently distributed. Regarding the other statistical parameters used to decide the satisfaction of the modelling, the values of adjusted $\mathrm{R}^{2}$ were higher than 0.80 .
The regression models explained $89.12 \%$, 94.92\%, and $92.01 \%$ of the total variability in PC, AoxA and TPC, respectively, with a significance level of $p<0.05$. The relative dispersion of the experimental points from the predictions of the models (CV) was observed to be $<10 \%$, and the lack of fit was not significant $(\mathrm{p}>0.05)$.

These values indicated that the experimental models were adequate and reproducible. In general, PC of germinated tepary bean flours increased with GT and Gt until reach highest value (360 g/kg, DW) at $40{ }^{\circ} \mathrm{C}$ and $170 \mathrm{~h}$ (Figure 1A). Similar to PC, AoxA also increased with GT and Gt until reaching a maximum value $[28,609 \mu \mathrm{mol} \mathrm{TE} / 100 \mathrm{~g}$ sample $(\mathrm{DW})]$ at $33^{\circ} \mathrm{C}$ and $134 \mathrm{~h}$, and after these germination conditions, AoxA delayed slightly (Figure 1B). In the case of the TPC response, a saddle behaviour was obtained (Figure 1C), and the stationary point was located at $33{ }^{\circ} \mathrm{C}$ and $80 \mathrm{~h}$ [TPC $=371 \mathrm{mg}$ GAE/100g sample (DW)]. In Figure $1 \mathrm{C}$, it can be observed that the surface curves up in temperature direction, and curves down in time direction. The highest value of TPC [463 mg GAE/100g sample (DW)] was observed at $20^{\circ} \mathrm{C}$ and $125 \mathrm{~h}$ (Figure 1C).

\section{Optimization}

Figure 1D, which was obtained of the superimposition of contour plots (Figures 1A, 1B and 1C), was utilized to determine the best combination of process variables for production of optimized germinated tepary bean (OGTBF). The central point of the optimization region in Figure 1D corresponds to the optimum combination of bioprocess variables $\left(\mathrm{GT}=32^{\circ} \mathrm{C} / \mathrm{Gt}=120 \mathrm{~h}\right)$ for OGTBF production with highest PC, AoxA, and TPC values. The predicted values of PC, AoxA, and TPC, using the predictive models of each response variable and the optimal conditions of bioprocessing, were $280 \mathrm{~g} / \mathrm{kg}(\mathrm{DW}), 28,358 \mu \mathrm{mol} \mathrm{TE} / 100$ sample (DW) (ABTS assay), and $349.7 \mathrm{mg}$ GAE/100 sample (DW), respectively. OGTBF was produced applying the best combination of germination bioprocess variables; the experiment using optimal conditions was replicated three times. The experimental values of PC, AoxA, and TPC of OGTBF (Tables 2 and 3) were similar to the predicted values, above mentioned, indicating that the optimal conditions of germination bioprocess were appropriated and reproducible.

\subsection{Chemical composition and nutritional properties of Optimized Germinated Tepary Bean Flour (OGTBF)}

As shown in Table 2, following germination at optimal conditions $\left(32^{\circ} \mathrm{C} / 120 \mathrm{~h}\right)$ a significant increase $(+58 \%)$ in tepary protein content was observed. This increase may be attributed to losses in dry weight, mainly loss in sugars during respiration due to a production of carbon dioxide and water, which escape from the seeds (Mbithi-Mwikya et al., 2000). During germination process, soluble sugars are produced due to the needs of growing plants (Omary et al., 2012).

The lipid content of tepary bean after germination at optimal conditions had a trend toward a significant $(\mathrm{p}<0.05)$ decline $(-28 \%)$ (Table 2). The decrease in sugar and fat contents of seeds during germination can be attributed to the production of energy required for metabolic activity, such as synthesis of 
(A)

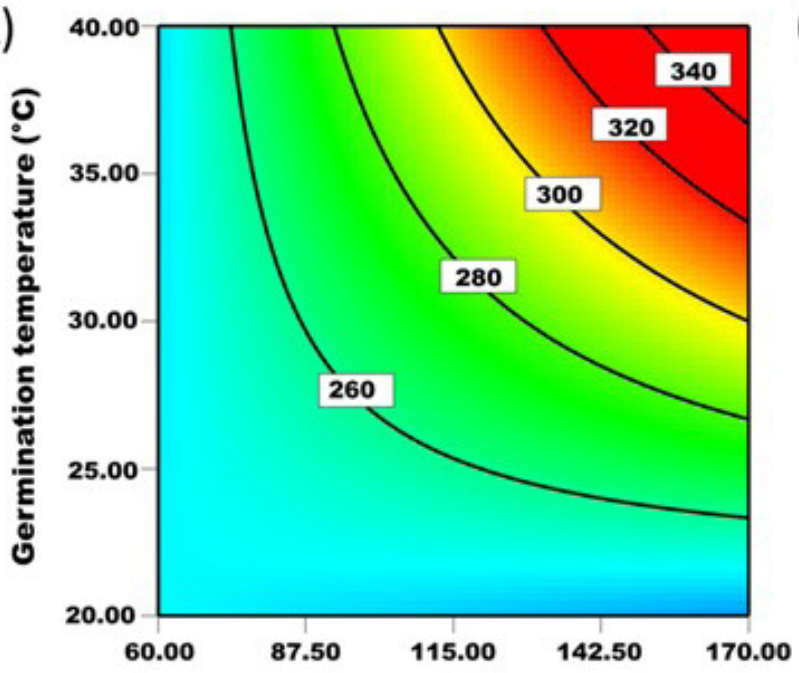

Germination time (h)

(C)

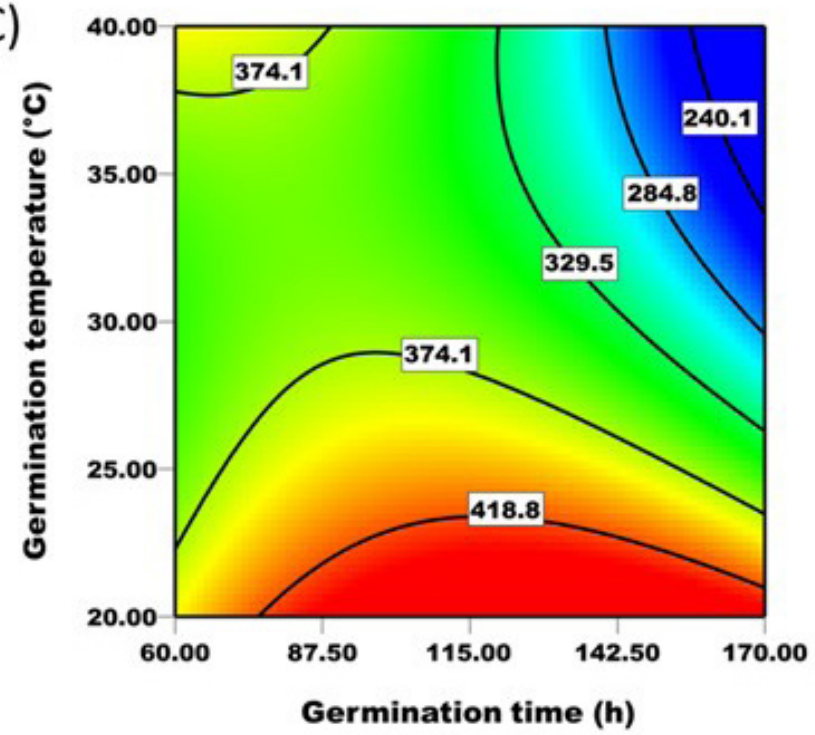

(B)

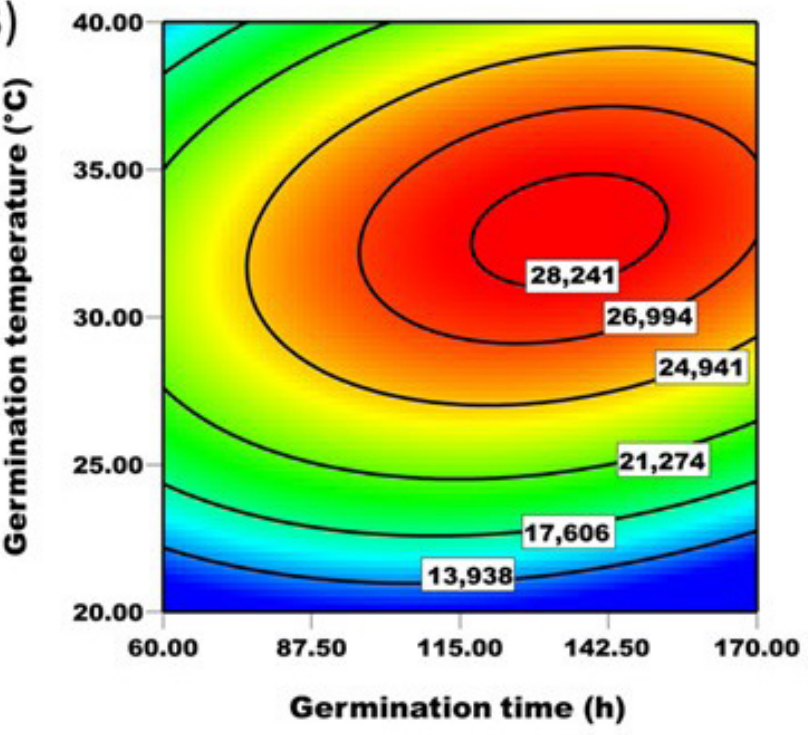

(D)

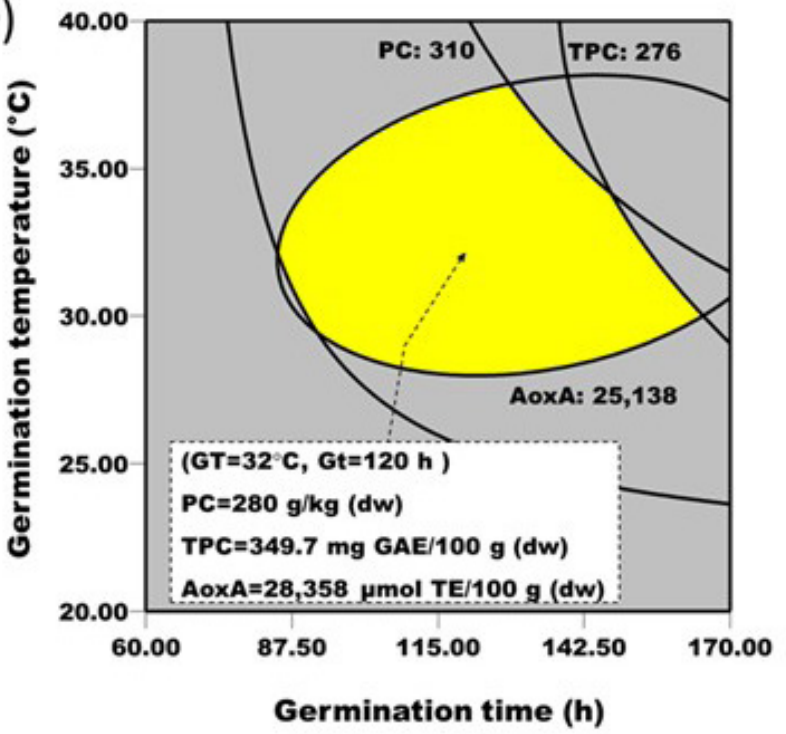

Figure 1. Contour plots showing the effect of germination temperature and time on (A) Protein content, (B) Antioxidant activity, and (C) Total phenolic compounds. (D) Region of the optimal combination of process variables (GT=Germination temperature, Gt=Germination time) for production of optimized germinated tepary bean flour (OGTBF) through germination bioprocess.

RNA, DNA, structural proteins, enzymes and other biological molecules (Khalil \& Mansour, 1995; Li et al., 2014).

Table 2 shows the effect of germination bioprocess on dietary fiber content in tepary bean seeds; soluble $(+400 \%)$, insoluble $(+237 \%)$, and total dietary $(+246 \%)$ fiber contents increased after germination. Megat et al. (2016) studied the effect of germination on dietary fiber in selected legumes; they found that soluble, insoluble, and total dietary fiber significantly increased in all germinated samples (kidney, mung, soybeans, peanuts). Cellulose, hemicellulose, and pectic polysaccharides increase during germination; also, the tissue histology and the protein-carbohydrate interaction are affected, which modify the structure of cell wall of the seeds (Martín-Cabrejas et al., 2003). It is well known that dietary fiber is part of a healthy diet. Studies have shown that the dietary fiber influences the gut physiology and protects against different diseases such as haemorrhoids or cardiovascular disease, atherosclerosis, dyslipidemia, hypertension, and some types of cancer (Kendall et al., 2010; Brownlee, 2011; Mackie et al., 2015; Zhu et al., 2015).

Table 2 shows the EAA content of unprocessed and germinated tepary bean flours (UTBF, OGTBF). In general, the EAA content wasn't significantly modified by germination bioprocess. The final EAA contents of UTBF and OGTBF were higher than those of the suggested pattern of EAA requirements for older children, adolescents and adults (3 years and older) (Food and Agriculture Organization, 2013); thus, in proteins of both samples, there was not limiting EAA with EAA score of 100. Similar results were reported by Idouraine et al. (1989). Also, the germination bioprocess not modified significantly the in vitro protein digestibility (IVPD) and the calculated protein efficiency ratio (C-PER) of tepary beans (Table 2). 
Table 2. Proximate composition and nutritional properties of unprocessed and optimized germinated tepary bean flours ${ }^{\mathbf{a}}$.

\begin{tabular}{|c|c|c|c|}
\hline Property & Unprocessed tepary bean flour & Optimized germinated tepary bean flour & (Food and Agriculture Organization, 2013) $^{\mathrm{b}}$ \\
\hline \multicolumn{4}{|c|}{ Chemical composition (g/kg flour, DW) } \\
\hline Lipids & $18 \pm 2^{\mathrm{A}}$ & $13 \pm 1^{\mathrm{B}}$ & --- \\
\hline Soluble fiber & $6 \pm 1^{\mathrm{B}}$ & $30 \pm 1^{\mathrm{A}}$ & --- \\
\hline Insoluble fiber & $92 \pm 2^{\mathrm{B}}$ & $310 \pm 30^{\mathrm{A}}$ & --- \\
\hline \multicolumn{4}{|l|}{$\mathrm{EAA}^{\mathrm{c}}(\mathrm{g} / \mathrm{kg}$ protein $)$} \\
\hline His & $24 \pm 3^{\mathrm{A}}$ & $26 \pm 2^{\mathrm{A}}$ & 16 \\
\hline Ile & $40 \pm 2^{\mathrm{A}}$ & $40 \pm 3^{\mathrm{A}}$ & 30 \\
\hline Leu & $69 \pm 5^{\mathrm{A}}$ & $72 \pm 7^{\mathrm{A}}$ & 61 \\
\hline Lys & $64 \pm 3^{A}$ & $63 \pm 5^{\mathrm{A}}$ & 48 \\
\hline Val & $47 \pm 3^{\mathrm{A}}$ & $46 \pm 3^{A}$ & 40 \\
\hline Total & 403 & 408 & 290.6 \\
\hline EAA chemical score (\%) & 100 & 100 & 100 \\
\hline Limiting EAA & --- & --- & --- \\
\hline $\operatorname{IVPD}^{\mathrm{d}}(\%)$ & $67 \pm 2^{\mathrm{A}}$ & $70 \pm 1^{\mathrm{A}}$ & --- \\
\hline C-PER ${ }^{\mathrm{e}}$ & 1.73 & 1.76 & --- \\
\hline
\end{tabular}

Table 3. Antioxidant activity and phytochemicals content of unprocessed and optimized germinated tepary bean flours ${ }^{\mathrm{a}}$.

\begin{tabular}{|c|c|c|}
\hline Property & Unprocessed tepary bean flour & Optimized germinated tepary bean flour \\
\hline \multicolumn{3}{|l|}{ Antioxidant activity ORAC ${ }^{b}$} \\
\hline Free phytochemicals & $2,446 \pm 317^{\mathrm{B}}$ & $18,325 \pm 736^{\mathrm{A}}$ \\
\hline Bound phytochemicals & $4,438 \pm 169^{\mathrm{B}}$ & $10,433 \pm 363^{\mathrm{A}}$ \\
\hline Total phytochemicals & $6,884 \pm 205^{\text {B }}$ & $28,758 \pm 533^{\mathrm{A}}$ \\
\hline \multicolumn{3}{|l|}{ Antioxidant activity $A B T S^{b}$} \\
\hline Free phytochemicals & $2,302 \pm 87^{\mathrm{B}}$ & $14,284 \pm 49^{\mathrm{A}}$ \\
\hline Bound phytochemicals & $5,867 \pm 60^{\text {в }}$ & $9,204 \pm 192^{\mathrm{A}}$ \\
\hline Total phytochemicals & $8,169 \pm 147^{\mathrm{B}}$ & $23,488 \pm 239^{\mathrm{A}}$ \\
\hline \multicolumn{3}{|l|}{ Phenolic content ${ }^{c}$} \\
\hline Free phenolics & $15 \pm 2^{\mathrm{B}}$ & $180 \pm 7^{\mathrm{A}}$ \\
\hline Bound phenolics & $92 \pm 1^{\mathrm{B}}$ & $175 \pm 8^{\mathrm{A}}$ \\
\hline Total phenolics & $107 \pm 2^{\mathrm{B}}$ & $355 \pm 10^{\mathrm{A}}$ \\
\hline \multicolumn{3}{|l|}{ Flavonoid content ${ }^{d}$} \\
\hline Free flavonoids & $30 \pm 1^{\mathrm{B}}$ & $98 \pm 10^{\mathrm{A}}$ \\
\hline Bound flavonoids & $54 \pm 2^{\mathrm{B}}$ & $82 \pm 3^{A}$ \\
\hline Total flavonoids & $84 \pm 2^{\mathrm{B}}$ & $180 \pm 10^{\mathrm{A}}$ \\
\hline
\end{tabular}

${ }^{a}$ Data are expressed as means \pm standard deviation. Means with different superscripts (A-B) in the same row are different (Duncan, $\left.\mathrm{p} \leq 0.05\right)$. ${ }^{\mathrm{b}} \mu \mathrm{mol}$ Trolox equivalents (TE)/100 $\mathrm{g}(\mathrm{DW})$. ${ }^{c} \mathrm{mg}$ Gallic acid equivalents (GAE)/100 g sample (DW). ${ }^{\mathrm{d}} \mathrm{mg}$ Quercetin equivalents (QE)/ $100 \mathrm{~g}$ sample (DW).

\subsection{Phenolic Content, Flavonoid Content and Antioxidant Activity (AoxA) of Optimized Germinated Tepary Bean Flour (OGTBF)}

As shown in Table 3 the germination bioprocess increased $(\mathrm{p}<0.05)$ free $(+1,100 \%)$, bound $(+90 \%)$, and total $(+232 \%)$ phenolic contents. Khang et al. (2016) investigated the phenolic profiles and AoxA of germinated legumes. These researchers reported that the phenolic concentration dramatically increased $(\mathrm{p}<0.05)$ in all legumes (Black, mung, and adzuki beans, soybeans, white cowpeas) after five days of germination at $30^{\circ} \mathrm{C}$. López-Amorós et al. (2006) observed that because of the metabolism initiates in the presence of water, the particles inside 
the grains change and produce energy and new compounds, including phenolics.

During germination there are release and biosynthesis of phenolic compounds, therefore this bioprocess can be considerate an efficient manner of increase the concentration of these compounds in seeds. The release of phenolic compounds such as hydroxycinnamates (e.g., Ferulic and p-Coumaric acids) is carried out by action of esterases (main enzymes that degrade cell wall), which break the ester and ether bonds existing between phenolic compounds and nonstarch polysaccharides in grain cell walls. While, in the case of the biosynthesis of phenolic compounds, it is carried out mainly by action of the phenylalanine ammonia lyase enzyme, which is actived during germination of seeds (Fernandez-Orozco et al., 2009; Ghiassi-Tarzi et al., 2012; Duodu, 2014). The germination process may produce positive changes in phenolics composition, and the dietary fiber and its association could improve nutritional and phytochemical quality and enhance the health-promoting properties of legumes (Dueñas et al., 2016).

After germination in optimal conditions $\left(32^{\circ} \mathrm{C} / 120 \mathrm{~h}\right)$ tepary bean seeds showed a significant increase $(\mathrm{p}<0.05)$ in free $(+227 \%)$, bound $(+52 \%)$, and total $(+114 \%)$ flavonoid contents (Table 3). Wu et al. (2012) reported that the germination is an effective bioprocess to increase isoflavonoids content as well as to improve the diversity of these compounds in germinated chickpea; they reported that germinated chickpea has more (4-fold) isoflavonoid content than soybean. The flavonoids have significant effects on prevention and treatment of cancer, which has been demonstrated in epidemiological studies and human clinical trials. Dietary bioactive compounds with anticarcinogenic activity such as flavonoids have been gaining interest among the scientific society because of their safety, the feasibility of oral administration, and cost-effectiveness (Lall et al., 2016).

In general, AoxA of tepary bean seeds increased after bioprocessing at optimal germination conditions $\left(32^{\circ} \mathrm{C} / 120 \mathrm{~h}\right)$ (Table 3). The AoxA, quantified by ORAC assay, for free (+649\%), bound $(+135 \%)$ and total $(+318 \%)$ phytochemicals increased after germination. Both, ORAC and ABTS methods, showed a similar tendency. Some researchers (Wu et al., 2012; Aguilera et al., 2013; Gharachorloo et al., 2013; Singh et al., 2014; Dueñas et al., 2016) also reported that the germination increased the AoxA of legumes. However, they did not evaluate AoxA in extracts of bound phenolics. The increase in AoxA with the germination bioprocess is one of the many metabolic changes that take place upon germination of seeds, mainly due to the rise in the content of phenolic compounds by the action of the endogenous hydrolytic enzymes. The increase in phenolic and flavonoid content and AoxA in chickpea seeds shows a potentially important role of phenolics during seed germination, as well as the potential enhancement of the nutraceutical value of seeds by the germination process (Cevallos-Casals \& Cisneros-Zevallos, 2010). Xue et al. (2016) carried out a study on bioactive compounds and antioxidant activity of mung and black bean, and soybean during the germination process. They reported, after an analysis of relative contribution, that total phenolics and total flavonoids made the highest (44.87-90.31\%) contribution to overall antioxidant activity.
However, in the present research, the phenolics and flavonoids contents and AoxA were measured using colourimetric methods, which have a limitation of interpretation of data due to many interferences in the generation of colour are present during the performance of the technique. Some reactions carried out between chemical reagents, and other no-phenolics compounds (e.g. protein peptides, amino acids, sugars, among others) presents in the extracts generate colour, which interferes with the measurement of the interest response.

Further research is needed to study the effect of the germination process over the content of specific bioactive compounds as phenolic acids and flavonoids in tepary bean. Furthermore, it is necessary to use a more reliable method for determining the in vitro antioxidant power of these bioactive compounds employing cellular systems, to define the possible beneficial antioxidant qualities and the potential health-relevant functionality of this germinated legume.

\section{Conclusions}

Although several underutilized legumes are traditionally used in different parts of the world, their full potential is yet to be recognised. Phaseolus acutifolius with rich proteins, carbohydrates, fiber, bioactive compounds, and outstanding agronomic characteristics qualifies its beneficial utilization in agriculture, foods and pharmaceutical industries in future. The optimum conditions for the production of germinated tepary bean flour with the highest protein, antioxidant activity and total phenolic values were: Germination temperature $=32{ }^{\circ} \mathrm{C} /$ Germination time $=120 \mathrm{~h}$. The optimized germination process also increased protein, dietary fiber, and flavonoids contents of tepary bean seeds. For this reason, the optimized germinated tepary bean flour could be considerated as functional food or ingredient rich in protein, dietary fiber, and natural antioxidants.

\section{References}

Adom, K. K., \& Liu, R. H. (2002). Antioxidant activity of grains. Journal of Agricultural and Food Chemistry, 50(21), 6182-6187. http://dx.doi. org/10.1021/jf0205099. PMid:12358499.

Aguilera, Y., Díaz, M. F., Jiménez, T., Benítez, V., Herrera, T., Cuadrado, C., Martín-Pedrosa, M., \& Martín-Cabrejas, M. A. (2013). Changes in nonnutritional factors and antioxidant activity during germination of nonconventional legumes. Journal of Agricultural and Food Chemistry, 61(34), 8120-8125. http://dx.doi.org/10.1021/jf4022652. PMid:23909570.

Association of Official Analytical Chemists - AOAC. (1999). Official Methods of Analysis (16th ed.). Washington: Association of Official Analytical Chemists.

Brownlee, I. A. (2011). The physiological roles of dietary fibre. Food Hydrocolloids, 25(2), 238-250. http://dx.doi.org/10.1016/j. foodhyd.2009.11.013.

Cevallos-Casals, B. A., \& Cisneros-Zevallos, L. (2010). Impact of germination on phenolic content and antioxidant activity of 13 edible seed species. Food Chemistry, 119(4), 1485-1490. http:// dx.doi.org/10.1016/j.foodchem.2009.09.030.

Dewanto, V., Wu, X., \& Liu, R. H. (2002). Processed sweet corn has higher antioxidant activity. Journal of Agricultural and Food 
Chemistry, 50(17), 4959-4964. http://dx.doi.org/10.1021/jf0255937. PMid:12166989.

Doblado, R., Frías, J., \& Vidal-Valverde, C. (2007). Changes in vitamin $\mathrm{C}$ content and antioxidant activity of raw and germinated cowpea (Vigna sinens var Carilla) seeds induced by high-pressure treatment. Food Chemistry, 101(3), 918-923. http://dx.doi.org/10.1016/j. foodchem.2006.02.043.

Dueñas, M., Sarmento, T., Aguilera, Y., Benitez, V., Mollá, E., Esteban, R. M., \& Martín-Cabrejas, M. A. (2016). Impact of cooking and germination on phenolic composition and dietary fibre fractions in dark beans (Phaseolus vulgaris L.) and lentils (Lens culinaris L.). Lebensmittel-Wissenschaft + Technologie, 66, 72-78. http://dx.doi. org/10.1016/j.lwt.2015.10.025.

Duodu, K. G. (2014). Effects of processing on phenolic phytochemicals in cereals and legumes. Cereal Foods World, 59(2), 64-70. http:// dx.doi.org/10.1094/CFW-59-2-0064.

Feng, S., Song, L. X., Lee, Y. K., \& Huang, D. J. (2010). The effects of fungal stress on the antioxidant contents of black soybeans under germination. Journal of Agricultural and Food Chemistry, 58(23), 12491-12496. http://dx.doi.org/10.1021/jf102926r. PMid:21058652.

Fernandez-Orozco, R., Frias, J., Zielinski, H., Muñoz, M., Piskula, M. K., Kozlowska, H., \& Vidal, C. (2009). Evaluation of bioprocesses to improve the antioxidant properties of chickpeas. Food Research Technology, 42, 885-892. http://dx.doi.org/10.1016/j.lwt.2008.10.013.

Food and Agriculture Organization - FAO (2013). Findings and recommendations of the 2011 FAO Expert Consultation on protein quality evaluation in human nutrition. In: Dietary protein quality evaluation in human nutrition: Report of an FAO expert consultation. (FAO Food and Nutrition Paper, Vol. 92). Rome: Food Agric Org United Nat.

Frassinetti, S., Gabriele, M., Caltavuturo, L., Longo, V., \& Pucci, L. (2015). Antimutagenic and antioxidant activity of a selected lectinfree common bean (Phaseolus vulgaris L.) in two cell-based models. Plant Foods for Human Nutrition (Dordrecht, Netherlands), 70(1), 35-41. http://dx.doi.org/10.1007/s11130-014-0453-6. PMid:25631277.

Gharachorloo, M., Ghiassi Tarzi, B., \& Baharinia, M. (2013). The effect of germination on phenolic compounds and antioxidant activity of pulses. Journal of the American Oil Chemists' Society, 90(3), 407-411. http://dx.doi.org/10.1007/s11746-012-2170-3.

Ghiassi Tarzi, B., Gharachorloo, M., Baharinia, M., \& Mortazavi, S. A. (2012). The effect of germination on phenolic content and antioxidant activity of chickpea. Iranian Journal of Pharmaceutical Research, 11(4), 1137-1143. PMid:24250547.

Heimler, D., Vignolini, P., Dini, M. G., \& Romani, A. (2005). Rapid tests to assess the antioxidant activity of Phaseolus vulgaris L dry beans. Journal of Agricultural and Food Chemistry, 53(8), 3053-3056. http://dx.doi.org/10.1021/jf049001r. PMid:15826058.

Hsu, H. W., Vavak, D. L., Satterlee, L. D., \& Miller, G. A. (1977). A multienzyme technique for estimating protein digestibility. Journal of Food Science, 42(5), 1269-1273. http://dx.doi.org/10.1111/j.1365-2621.1977. tb14476.x.

Idouraine, A., Tinsley, A. M., \& Weber, C. W. (1989). Nutritional quality and sensory acceptability of akara prepared from germinated tepary beans. Journal of Food Science, 54(1), 114-117. http://dx.doi. org/10.1111/j.1365-2621.1989.tb08580.x.

Kalogeropoulos, N., Chiou, A., Ioannou, M., Karathanos, V. T., Hassapidou, M., \& Andrikopoulos, N. K. (2010). Nutritional evaluation and bioactive microconstituents (phytosterols, tocopherols, polyphenols, triterpenic acids) in cooked dry legumes usually consumed in the Mediterranean countries. Food Chemistry, 121(3), 682-690. http:// dx.doi.org/10.1016/j.foodchem.2010.01.005.
Katoch, R. (2013). Nutritional potential of rice bean (Vigna umbellata): An underutilized legume. Journal of Food Science, 78(1), C8-C16. http://dx.doi.org/10.1111/j.1750-3841.2012.02989.x. PMid:23278402.

Kendall, C. W. C., Esfahani, A., \& Jenkins, D. J. A. (2010). The link between dietary fibre and human health. Food Hydrocolloids, 24(1), 42-48. http://dx.doi.org/10.1016/j.foodhyd.2009.08.002.

Khalil, A. H., \& Mansour, E. H. (1995). The effect of cooking, autoclaving and germination on the nutritional quality of faba beans. Food Chemistry, 54(2), 177-182. http://dx.doi.org/10.1016/0308-8146(95)00024-D.

Khang, D. T., Dung, T. N., Elzaawely, A. A., \& Xuan, T. D. (2016). Phenolic profiles and antioxidant activity of germinated legumes. Foods, 5(2), 1-10. http://dx.doi.org/10.3390/foods5020027. PMid:28231122.

Khattak, A. B., Zeb, A'., \& Bibi, N. (2008). Impact of germination time and type of illumination on carotenoid content, protein solubility and in vitro protein digestibility of chickpea (Cicer arietinum $\mathrm{L}$ ) sprouts. Food Chemistry, 109(4), 797-801. http://dx.doi.org/10.1016/j. foodchem.2008.01.046. PMid:26049993.

Kuo, Y.-H., Rozan, P., Lambein, F., Frias, J., \& Vidal-Valverde, C. (2004). Effects of different germination conditions on the contents of free protein and non-protein amino acids of commercial legumes. Food Chemistry, 86(4), 537-545. http://dx.doi.org/10.1016/j. foodchem.2003.09.042.

Lall, R. K., Adhami, V. M., \& Mukhtar, H. (2016). Dietary flavonoid fisetin for cancer prevention and treatment. Molecular Nutrition \& Food Research, 60(6), 1396-1405. http://dx.doi.org/10.1002/ mnfr.201600025. PMid:27059089.

Li, Y. C., Qian, H., Sun, X. L., Cui, Y., Wang, H. Y., Du, C., \& Xia, X. H. (2014). The effects of germination on chemical composition of peanut seed. Food Science and Technology Research, 20(4), 883-889. http://dx.doi.org/10.3136/fstr.20.883.

López, S. J. L., Ruiz, C. J. A., Sánchez, G. J. J., \& Lépiz, I. R. (2005). Adaptación climática de 25 species de frijol Silvestre (Phaseolus spp) en la república Mexicana. Revista Fitotecnia Mexicana, 28, 221-229.

López-Amorós, M. L., Hernández, T., \& Estrella, I. (2006). Effect of germination on legume phenolic compounds and their antioxidant activity. Journal of Food Composition and Analysis, 19(4), 277-283. http://dx.doi.org/10.1016/j.jfca.2004.06.012.

López-Cervantes, J., Sánchez-Machado, D. I., \& Rosas-Rodríguez, J. A. (2006). Analysis of free amino acids in fermented shrimp waste by high-performance liquid chromatography. Journal of Chromatography. A, 1105(1-2), 106-110. http://dx.doi.org/10.1016/j. chroma.2005.08.040. PMid:16439254.

Mackie, A., Bajka, B., \& Rigby, N. (2015). Roles for dietary fibre in the upper GI tract: The importance of viscosity. Food Research International. http://dx.doi.org/10.1016/j.foodres.2015.11.011.

Martín-Cabrejas, M. A., Ariza, N., Esteban, R., Mollá, E., Waldron, K., \& López-Andréu, F. J. (2003). Effect of germination on the carbohydrate composition of the dietary fiber of peas (Pisum sativum $\mathrm{L}$ ). Journal of Agricultural and Food Chemistry, 51(5), 1254-1259. http://dx.doi. org/10.1021/jf0207631. PMid:12590464.

Mbithi-Mwikya, S., Van Camp, J., Yiru, Y., \& Huyghebaert, A. (2000). Nutrient and antinutrient changes in finger millet (Eleusine coracan) during sprouting. Lebensmittel-Wissenschaft + Technologie, 33(1), 9-14. http://dx.doi.org/10.1006/fstl.1999.0605.

Megat, R. M. R., Azrina, A., \& Norhaizan, M. E. (2016). Effect of germination on total dietary fibre and total sugar in selected legumes. International Food Research Journal, 23, 257-261.

Miklas, N. P., \& Staveley, J. R. (1998). Incomplete dominance of rust resistance in tepary bean. Horticultural Science, 33, 143-145. 
Omary, M. B., Fong, C., Rothschild, J., \& Finney, P. (2012). Effects of germination on the nutritional profile of gluten-free cereals and pseudocereals. A review. Cereal Chemistry, 89(1), 1-14. http://dx.doi. org/10.1094/CCHEM-01-11-0008.

Ou, B., Hampsch-Woodill, M., \& Prior, R. L. (2001). Development and validation of an improved oxygen radical absorbance capacity assay using fluorescein as the fluorescent probe. Journal of Agricultural and Food Chemistry, 49(10), 4619-4626. http://dx.doi.org/10.1021/ jf010586o. PMid:11599998.

Perales-Sánchez, J. X., Reyes-Moreno, C., Gómez-Favela, M. A., MilánCarrillo, J., Cuevas-Rodríguez, E. O., Valdez-Ortiz, A., \& GutiérrezDorado, R. (2014). Increasing the antioxidant activity and total phenolic and flavonoid contents by optimizing the germination conditions of amaranth seeds. Plant Foods for Human Nutrition (Dordrecht, Netherlands), 69(3), 196-202. http://dx.doi.org/10.1007/ s11130-014-0430-0. PMid:24958279.

Re, R., Pellegrini, N., Proteggente, A., Pannala, A., Yang, M., \& RiceEvans, C. (1999). Antioxidant activity applying an improved ABTS radical cation decolourization assay. Free Radical Biology \& Medicine, 26(9-10), 1231-1237. http://dx.doi.org/10.1016/S08915849(98)00315-3. PMid:10381194.

Salgado, M. O., Schwartz, H. F., Brick, M. A., \& Pastor, M. A. (1994). Resistance to Fusarium oxysporum f, sp phaseoli in tepary beans (Phaseolus acutifolius). Plant Disease, 78(4), 357-360. http://dx.doi. org/10.1094/PD-78-0357.

Scheerens, J. C., Tinsley, A. M., Abbas, F. R., Weber, C. W., \& Berry, J. W. (1983). The nutritional significance of tepary bean consumption. Desert Plants, 5, 11-56.

Shams Ardekani, M. R., Hajimahmoodi, M., Oveisi, M. R., Sadeghi, N., Jannat, B., Ranjbar, A. M., Gholam, N., \& Moridi, T. (2011). Comparative antioxidant activity and total flavonoid content of Persian pomegranate (Punica granatum L.) cultivars. Iranian Journal of Pharmaceutical Research, 10(3), 519-524. PMid:24250384.

Shi, H., Nam, P., \& Ma, Y. (2010). Comprehensive profiling of isoflavones, phytosterols, tocopherols, minerals, crude protein, lipid, and sugar during soybean (Glycine max) germination. Journal of Agricultural and Food Chemistry, 58(8), 4970-4976. http://dx.doi.org/10.1021/ jf100335j. PMid:20349962.

Singh, P. K., Gautam, A. K., Panwar, H., Sing, D. K., Srivastava, N., Bhagyawant, S. S., \& Upadhyay, H. (2014). Effects of germination on antioxidant and anti nutritional factors of commonly used pulses. International Journal of Research in Chemistry and Environment, $4,100-104$.

Singleton, V. L., Orthofer, R., \& Lamuela-Raventós, R. M. (1999). Analysis of total phenols and other oxidation substrates and antioxidants by means of Folin-Ciocalteu reagent. Methods in Enzymology, 299, 152-178. http://dx.doi.org/10.1016/S0076-6879(99)99017-1.

Sridhar, K. R., \& Niveditha, V. R. (2014). Nutritional and bioactive potential of coastal sand dune wild legume Canavalia maritima (Aubl) Thou. - An overview. Indian Journal of Natural Products and Resources, 6, 107-120.

Wu, Z., Song, L., \& Huang, D. (2011). Food grade fungal stress on germinating peanut seeds induced phytoalexins and enhanced polyphenolic antioxidants. Journal of Agricultural and Food Chemistry, 59(11), 5993-6003. http://dx.doi.org/10.1021/jf200776w. PMid:21545178.

Wu, Z., Song, L., Feng, S., Liu, Y., He, G., Yioe, Y., Liu, S. Q., \& Huang, D. (2012). Germination Dramatically Increases Isoflavonoid Content and Diversity in Chickpea (Cicer arietinum L.) Seeds. Journal of Agricultural and Food Chemistry, 60(35), 8606-8615. http://dx.doi. org/10.1021/jf3021514. PMid:22816801.

Xue, Z., Wang, C., Zhai, L., Yu, W., Chang, H., Kou, X., \& Zhou, F. (2016). Bioactive compounds and antioxidant activity of mung bean (Vigna radiata L.), soybean (Glicine max L.) and black bean (Phaseolus vulgaris L.) during the germination process. Czech Journal of Food Sciences, 34(1), 68-78. http://dx.doi.org/10.17221/434/2015-CJFS.

Zhu, F., Du, B., Zheng, L., \& Li, J. (2015). Advance on the bioactivity and potential applications of dietary fibre from grape pomace. Food Chemistry, 186, 207-212. http://dx.doi.org/10.1016/j. foodchem.2014.07.057. PMid:25976812. 